\title{
The Physiological Effect of Aureococcus anophagefferens ("brown tide") on the Lateral Cilia of Bivalve Mollusks*
}

\author{
LOUIS F. GAINEY, JR. ${ }^{1}$ AND SANDRA E. SHUMWAY ${ }^{2,3}$ \\ ${ }^{1}$ Department of Biological Sciences, University of Southern Maine, Portland, Maine 04103 and \\ ${ }^{2}$ Maine Department of Marine Resources, ${ }^{3}$ Bigelow Laboratory for Ocean Sciences, \\ W. Boothbay Harbor, Maine 04575
}

\begin{abstract}
The "brown tide" alga, Aureococcus anophagefferens, had no effect on the activity of the lateral cilia of isolated gills of the bivalve mollusks Argopecten irradians, Geukensia demissa, and Mya arenaria. A. anophagefferens caused a significant decrease in the activity of lateral cilia of five other bivalve mollusks, Crassostrea virginica, Ostrea edulis, Mercenaria mercenaria, Modiolus modiolus, and Mytilus edulis. Exposure of isolated gills of $M$. edulis to the water from which $A$. anophagefferens had been removed, or to polystyrene beads at the same concentration as $A$. anophagefferens, had no effect upon the activity of the lateral cilia. Thus, the inhibition of the lateral cilia is not caused by a compound excreted into the water, nor is it the result of the high density of cells. The response of lateral cilia to dopamine was identical to the response to $A$. anophagefferens; lateral cilia that were inhibited by dopamine were also inhibited by $A$. anophagefferens. Pretreatment of the gills of $M$. edulis with the dopamine antagonist ergometrine blocked the inhibition of the lateral cilia by both dopamine and $A$. anophagefferens. A water-soluble inhibitory compound was released from $A$. anophagefferens by exposing the cells to amylase, and then removing the cells by filtration. The effect of this inhibitory compound was also blocked by ergometrine. We propose that the isolated gills are digesting the extracellular coat of $A$. anophagefferens releasing a water soluble dopamine-mimetic compound that causes inhibition of lateral cilia.
\end{abstract}

Received 12 February 1991; accepted 2 July 1991.

* Publication No. 296 of the Tallahassee, Sopchoppy \& Gulf Coast Marine Biological Association.

\section{Introduction}

Monospecific blooms of a small, previously undescribed, coccoid chrysophycean alga (approximately $2 \mu \mathrm{m}$ in diameter) began to plague coastal embayments of the northeastern United States during the summer of 1985 , with recurrent blooms in some areas continuing through 1990. Concurrent blooms were reported in Gardiners Bay, Great South Bay, and Peconic Bay, Long Island, New York; Narragansett Bay, Rhode Island; and Barnegat Bay, New Jersey (Tracey, 1985; Olsen, 1986; Sieburth et al., 1986; Cosper et al., 1987). Concentrations as high as $10^{6}$ cells $\mathrm{ml}^{-1}$ were recorded and resulted in discoloration of the waters and thus the term "brown tide" (Cosper et al., 1987; Sieburth et al., 1988). The organism has since been identified as Aureococcus anophagefferens (Seiburth et al., 1986, 1988).

The effects of these "brown tides" on shellfish populations were immediately evident and, in some cases, catastrophic (Shumway, 1990). Bricelj et al. (1987) reported recruitment failure and starvation of post-reproductive adult bay scallops, Argopecten irradians, in eastern Long Island embayments. Mussels, Mytilus edulis, suffered reproductive failure and mortalities ranging from 30 to $100 \%$ of natural and transplanted animals in Narragansett Bay, Rhode Island (Tracey, 1988). The mechanisms responsible for these mortalities remain unclear (Tracey, 1985; Bricelj and Kuenstner, 1989). Bricelj and Kuenstner (1989) suggested that the adverse effects of $A$. anophagefferens on bivalve mollusks may be a result of small size, high density, poor digestibility, toxicity, or deficiency in essential micronutrients.

The efficiency with which bivalve mollusks can retain particles filtered from seawater varies between species of 
shellfish and is, in most cases, directly related to the size of the algal cells with small cells generally retained less efficiently than larger cells (Mohlenberg and Riisgard, 1978; Bayne and Newell, 1983). The very small size of $A$. anophagefferens led investigators to determine the effects of this alga on feeding rates in several species of bivalve mollusks. Scallops, A. irradians, and mussels, $M$. edulis, retained filtered cells with only 36 and $59 \%$ efficiency, respectively (Bricelj and Kuenstner, 1989), compared to $100 \%$ efficiency when fed cells with a diameter greater than $5 \mu \mathrm{m}$ (Bayne and Newell, 1983). Furthermore, feeding rates in both species were significantly depressed when fed cultured $A$. anophagefferens at bloom densities. Reduced clearance rates have been observed in $M$. edulis and the quahog, Mercenaria mercenaria, in the presence of $A$. anophagefferens; reductions in clearance rates by the mussels were independent of particle size, and substances dissolved in bloom waters had no effect on clearance rates (Tracey, 1988; Tracey et al., 1990). While specific cell toxins have not been identified from $A$. anophagefferens, there is morphological and physiological evidence to suggest that toxicity is related to a component of the cell surface. (Tracey et al., 1988, 1990; Draper et al., 1990).

Although the small size and high density of $A$. anophagefferens had detrimental effects on bay scallops, these effects were not enough to account for the starvation experienced by scallops in the field; these results might be ascribed to toxic effects following more prolonged exposure to bivalves to Aureococcus cells (Bricelj and Kuenstner, 1989). Other authors have also suggested that chronic toxicity of $A$. anophagefferens cells at high densities might be responsible for the detrimental effects observed in bivalve mollusks (Tracey et al., 1988). There is strong evidence that chronic toxicity at high densities, rather than small size, indigestibility, or poor nutritional quality is responsible for the detrimental effects seen in bivalves (Tracey, 1988; Bricelj and Kuenstner, 1989; Bricelj et al., 1989; Gallager et al., 1989; Draper et al., 1990). Recent studies indicate that direct contact with Aureococcus cells is necessary to inhibit grazing (Tracey, 1988; Gallager et al., 1989; Ward and Targett, 1989; Draper et al., 1990).

The control of lateral ciliary activity in bivalve mollusks, in particular Mytilus edulis, has been studied extensively during the last 70 years, and there is considerable evidence that dopamine is an inhibitory neurotransmitter involved in regulation of lateral cilia (for a review of early work, see Aiello, 1960). Exogenously applied dopamine inhibits the lateral cilia of $M$. edulis and Crassostrea virginica but not Geukensia demissa (Paparo and Aicllo, 1970; Catapane, 1983; Paparo, 1985). In addition, high frequency stimulation of the cerebro-visceral nerve connective of $M$. edulis resulted in inhibition of the lateral cilia; this response was abolished by pretreating the gill or visceral ganglion with the antagonist ergometrine, which also blocked the effects of exogenously applied dopamine (Catapane et al., 1978, 1979). Dopamine has been localized in the branchial nerve fibers of $M$. edulis, and these fibers appear to make synaptic contact with the lateral ciliary cells (Stefano and Aiello, 1975; Paparo, 1972). Paparo and Finch (1972) showed that isolated gills metabolized DOPA and tyrosine to dopamine.

Calcium has also been shown to regulate the activity of lateral cilia. For example, the lateral cilia of isolated gills and triton-extracted cells will beat in the absence of extracellular calcium, while an increase in the concentration of intracellular calcium will cause inhibition of the lateral cilia (Walter and Satir, 1978; Paparo, 1980; Murakami, 1983; Stommel and Stevens, 1985). Paparo and Murphy (1975) proposed that the inhibitory effects of dopamine on the lateral cilia are mediated by an influx of calcium, and studies on mammalian systems support this hypothesis (Ahlijanian and Cooper, 1988; Felder et al., 1989; Mahan et al., 1990).

In the present study, we examined the effects of $\mathrm{Au}$ reococcus anophagefferens and dopamine on the activity of the lateral cilia of eight species of bivalve mollusks. In addition, we examined the effects of polystyrene microspheres, the culture media from which $A$. anophagefferens had been removed by filtration, and the culture media from which $A$. anophagefferens treated with amylase had been removed by filtration on the activity of the lateral cilia of Mytilus edulis. Preliminary results of this study were presented at the Fourth International Conference on Toxic Marine Phytoplankton (Draper et al., 1990) and to the American Society of Zoologists (Gainey and Shumway, 1989).

\section{Materials and Methods}

The original non-axenic culture of Aureococcus anophagefferens was supplied by E. M. Cosper (MSRC, State University of New York, Stony Brook). The culture was maintained at $18^{\circ} \mathrm{C}$ in an $\mathrm{f} / 2$ medium with $.01 \mathrm{mM}$ disodium glycero-phosphate added and sodium silicate omitted (Guillard, 1975). Cells were harvested during the late exponential growth phase as toxicity varies in relation to environmental growth conditions (Tracey et al., 1990). Adult specimens of bivalves were collected at the following localities: Mytilus edulis, Falmouth; Mya arenaria, Boothbay Harbor; Modiolus modiolus, Damariscotta River; Crassostrea virginica and Ostrea edulis, Mook Sea Farms, Damariscotta (all in Maine); Argopecten irradians, Shinnecock Bay, Southhampton, New York; Geukensia demissa, Sakonnet River, Tiverton, Rhode Island; and Mercenaria mercenaria, Wachapreague, Virginia. With the exception of Mytilus edulis, all animals were main- 
tained at the Maine Department of Marine Resources Laboratory, Boothbay Harbor, in running seawater at temperatures ranging from 9 to $12^{\circ} \mathrm{C}$ and a salinity of 33 $\%$. Prior to use in experiments, animals were held at $10^{\circ} \mathrm{C}$, $30 \%$ salinity on a $12 \mathrm{~h}$ light-dark cycle at the University of Southern Maine, Portland, for periods ranging from 1 week to a month.

Gills were dissected distal to the visceral ganglion and were then separated into demibranchs. The isolated demibranchs were pinned to strips of rubber band that had been glued to the bottom of petri dishes. The dishes were filled with $10 \mathrm{ml}$ of artificial seawater with an ionic composition as follows: $\mathrm{CaCl}_{2}=10 \mathrm{~m} M, \mathrm{KCl}=9.8 \mathrm{~m} M$, $\mathrm{MgCl}_{2}=53 \mathrm{~m} M, \mathrm{NaBr}=.57 \mathrm{~m} M, \mathrm{NaCl}=400 \mathrm{~m} M$, $\mathrm{NaHCO}_{3}-2.5 \mathrm{~m} M, \mathrm{Na}_{2} \mathrm{SO}_{4}=28 \mathrm{~m} M$ (ASW, Welsh $e t$ al., 1968). The gills were used after the appearance of metachronal waves on the lateral cilia, usually within 1 to $12 \mathrm{~h}$ after dissection, depending upon the species.

The gills were observed at a magnification of $100 \times$ with a compound microscope with the substage illuminator replaced with a mirror. The rate of lateral ciliary beating was determined using a Pasco Sf-9211 strobe driven by a Grass SD-9 stimulator. The gills were initially viewed at a flashing rate of $60 \mathrm{~Hz}$, which was above the frequency of flicker fusion for our eyes; the flashing rate of the strobe was then decreased until the metachronal waves appeared motionless in the shape of a horseshoe. At harmonics above the actual ciliary rate, the wavelength of the metachronal waves appeared shorter than the true wavelength and the waves appeared to flicker (Catapane et al., 1978, pers. obs.). Harmonics below the actual ciliary rate were avoided by always starting the strobe at a higher frequency than the actual rate.

Gills were first observed in artificial sea water; for the treatments, the artificial sea water was replaced with $A$. anophagefferens at concentrations of approximately $10^{6}$ cells/ml. Readings were taken every hour for at least $5 \mathbf{h}$ and again at $24 \mathrm{~h}$ for Geukensia demissa, Mya arenaria, Mercenaria mercenaria, and Mytilus edulis. Due to the fragility of the gills in Argopecten irradians, Crassostrea virginica, Ostrea edulis, and Modiolus modiolus, it was not possible to take readings at $24 \mathrm{~h}$. All experiments were performed at $10^{\circ} \mathrm{C}$.

\section{Effects of dissolved exudates}

Suspensions of $A$. anophagefferens were filtered through a $0.8 \mu \mathrm{m}$ filter using the minimal vacuum possible to maintain flow through the filter; the filtered cells were viewed microscopically to insure that cell lysis did not occur. This filtrate was added to isolated gills of Mytilus edulis and ciliary rates were measured as described previously.

\section{Effects of particulates}

Isolated gills of $M$. edulis were exposed to $2.9 \mu \mathrm{m}$ diameter polystyrene microspheres at a concentration of $7.85 \times 10^{6}$ spheres $/ \mathrm{ml}$. The microspheres were obtained from Polysciences, Inc., Warrington, Pennsylvania.

\section{Effects of dopamine}

The effects of dopamine on the lateral cilia of Mytilus edulis, Geukensia demissa, and Crassostrea virginica have been described previously (Paparo and Aiello, 1970; Catapane, 1983; Paparo, 1985). We tested the effects of dopamine on these bivalves as well as the others used in this study. Isolated gills were exposed to $10^{-4} \mathrm{M}$ dopamine in ASW; this concentration is an order of magnitude greater than necessary to cause complete lateral ciliary arrest in Mytilus edulis (Catapane, 1983). The presence or absence of metachronal waves was noted immediately after the addition of dopamine and every 2 min thereafter for 20 min. If the lateral cilia ceased beating within this period, the response to dopamine was considered positive.

\section{Effect of ergometrine}

Catapane et al. (1978) demonstrated that application of $10^{-5} \mathrm{M}$ ergometrine (ergonovine) to the isolated gills of Mytilus edulis had no effect on the rate of previously beating lateral cilia. Catapane et al. (1979) also demonstrated that application of $10^{-5} \mathrm{M}$ ergometrine to the visceral ganglion blocked the lateral ciliary inhibition brought about by the addition of $10^{-4} \mathrm{M}$ dopamine to the visceral ganglion if the ergometrine was added $10 \mathrm{~min}$ prior to the addition of dopamine. To determine if ergometrine would also block the lateral ciliary inhibition brought about by exposure of the isolated gills of $M$. edulis to $10^{-4}$ $M$ dopamine, we exposed isolated gills to $10^{-5} M$ ergometrine. We then added fresh $10^{-4} M$ dopamine in ASW hourly for $4 \mathrm{~h}$ and again at $24 \mathrm{~h}$. Both ergometrine and dopamine were purchased from Sigma Chemical Co.

\section{Effects of amylase}

Cultures of $A$. anophagefferens were exposed to a saturated solution of alpha amylase (Type I-A, Sigma Chemical Co, $4 \mathrm{mg} / \mathrm{ml}$ ) for at least $16 \mathrm{~h}$. The Aureococcus amylase mixture was then filtered through an $0.8 \mu \mathrm{m}$ filter as described previously. Isolated gills of $M$. edulis were exposed to amylase at the same concentration to test the effects of amylase on lateral ciliary activity.

Ciliary rates were expressed as a percentage of the initial rate of each isolated gill preparation. The effects of various experimental treatments were evaluated using an $\mathrm{F}$ test, with the mean square for experimental treatment as a numerator and the mean square for animal nested within treatment, where animal was a class variable that repre- 
sented repeated measures on the same piece of gill, as an error term. Superscripts and subscripts for F values represent degrees of freedom for the numerator and denominator. The Type III mean squares used for this test were generated using the model: percent initial rate $=$ treatment time animal (treatment). The statistical procedures were performed using the general linear model program (Proc GLM) in version 5 of the Statistical Analysis System (S^S). Tests were considered significant at probabilities less than 0.05 . Errors and error bars are \pm 1 standard error. Although readings were taken on experimental and control groups at the same time intervals, the groups have been offset by $15 \mathrm{~min}$ in all figures for the sake of clarity.

\section{Results}

\section{Basal ciliary rates}

The mean lateral ciliary rate of the eight species of bivalves prior to exposure to Aureococcus anophagefferens ranged from a low of $17 \mathrm{~Hz}$ in Geukensia demissa to a high of $25 \mathrm{~Hz}$ in Crassostrea virginica (Table I).

\section{The response of bivalve gills to $\mathrm{A}$. anophagefferens}

Aureococcus anophagefferens had no significant effect on the activity of the lateral cilia of the following species of bivalve mollusks: Argopecten irradians $\left(\mathrm{F}_{20}^{1}=.07, P\right.$ $=.79)$, Geukensia demissa $\left(\mathrm{F}_{24}^{1}=.98, P=.33\right)$, and $M y a$ arenaria $\left(\mathrm{F}_{16}^{1}=.00, P=.97\right.$, Fig. 1$)$.

A. anophagefferens inhibited the lateral cilia in the following species of bivalves: Crassostrea virginica $\left(\mathrm{F}_{30}^{1}=36.44, P=.0001\right)$, Ostrea edulis $\left(\mathrm{F}_{30}^{1}=35.73, P\right.$ $=.0001)$, Mercenaria mercenaria $\left(\mathrm{F}_{21}^{1}=7.30, P=.01\right)$, Modiolus modiolus $\left(\mathrm{F}_{22}^{1}=36.44, P=.001\right)$, and Mytilus edulis $\left(\mathrm{F}_{22}^{1}=13.91, P=.001\right.$, Fig. 1$)$. All of these species exhibited depressed lateral ciliary activity within $1 \mathrm{~h}$ after exposure to $A$. anophagefferens, with the exception of $M$. modiolus, where the mean rate did not begin to decline until $3 \mathrm{~h}$ after exposure.

The time until maximal ciliary inhibition, and the magnitude of the inhibition, was species specific. For example, in M. edulis the mean rate declined to $48 \%$ ( \pm 10.2 , $\mathrm{n}=16$ ) of the initial rate $3 \mathrm{~h}$ after exposure. In C. virginica, the mean rate declined to only $75 \%( \pm 3.4, n=24)$ of the initial rate $4 \mathrm{~h}$ after exposure, while in $M$. modiolus the mean rate declined to $89 \%( \pm 0.86, \mathrm{n}=18)$ of the initial rate $5 \mathrm{~h}$ after exposure. In both $O$. edulis and $M$. mercenaria, the mean rates were $78 \%( \pm 1.4, \mathrm{n}=24)$ and $32 \%$ $( \pm 15, \mathrm{n}=15)$ of the initial rates respectively, $6 \mathrm{~h}$ after exposure.

In $M$. edulis and $M$. mercenaria, the gills were hardy enough to carry out observations for longer periods of time than was possible for some of the other species. Twenty-four hours after exposure, the mean, ciliary rate
Table I

Mean lateral ciliary rates (beats/s), rounded to the nearest integer, of bivales used in this study

\begin{tabular}{lccc}
\hline \hline \multicolumn{1}{c}{ Species } & $\begin{array}{c}\text { Mean rate } \\
\text { (beats/s) }\end{array}$ & $\begin{array}{c}\text { Standard } \\
\text { error }\end{array}$ & $n$ \\
\hline Argopecten irradians & 24 & 1.6 & 22 \\
Geukensia demissa & 17 & .47 & 26 \\
Mya arenaria & 20 & 1.42 & 18 \\
Crassostrea virginica & 25 & .12 & 32 \\
Ostrea edulis & 24 & .29 & 32 \\
Mercenaria mercenaria & 20 & .45 & 23 \\
Modiolus modiolus & 20 & .08 & 24 \\
Mytilus edulis & 19 & .74 & 25 \\
\hline
\end{tabular}

of $M$. mercenaria had risen to $85 \%( \pm 6.5, \mathrm{n}=15)$, while the controls had a mean rate of $96 \%( \pm 3.7, n=8)$ of the initial rate. Twenty-four hours after exposure, the mean rate of $M$. edulis had risen to $94 \%( \pm 15, \mathrm{n}=16)$, while the controls had a mean rate of $108 \%( \pm 7.3, n=9)$ of the initial rate.

\section{The nature of ciliary inhibition in Mytilus edulis}

To determine if ciliary inhibition was caused by an exudate of $A$. anophagefferens, we exposed isolated gills of $M$. edulis to seawater from which $A$. anophagefferens had been removed by filtration. This water had no effect upon lateral ciliary activity $\left(\mathrm{F}_{16}^{1}=.56, P=.46\right.$, Fig. 2$)$.

To determine if ciliary inhibition was caused by the presence of high concentrations of particulate matter, we exposed isolated gills of $M$. edulis to polystyrene microspheres. The microspheres had no effect upon lateral ciliary activity $\left(\mathrm{F}_{15}^{1}=.69, P=.42\right.$, Fig. 3$)$.

All of the species tested that showed lateral ciliary inhibition upon exposure to $A$. anophagefferens also showed lateral ciliary inhibition upon exposure to $10^{-4} \mathrm{M}$ dopamine; moreover, those species that did not have lateral ciliary inhibition upon exposure to $A$. anophagefferens were not inhibited by exposure to dopamine (Table II).

To determine if the inhibition of lateral cilia caused by exposure to $A$. anophagefferens was caused by dopamine, or a dopamine agonist, we first exposed isolated gills to $10^{-5} M$ ergometrine and then to fresh $10^{-4} M$ dopamine hourly for $4 \mathrm{~h}$ and again at $24 \mathrm{~h}$ to test whether ergometrine would block the inhibition brought about by dopamine. There was no difference in the rates of these gills after these treatments $\left(\mathrm{F}_{20}^{4}=.03, P=.99\right)$, i.e., the single dose of ergometrine blocked the effects of dopamine for $24 \mathrm{~h}$. We then exposed isolated gills of $M$. edulis to $10^{-5}$ $M$ ergometrine for $10 \mathrm{~min}$ prior to exposure to $A$. anophagefferens. Gills pretreated with ergometrine showed no inhibition when exposed to $A$. anophagefferens, in 

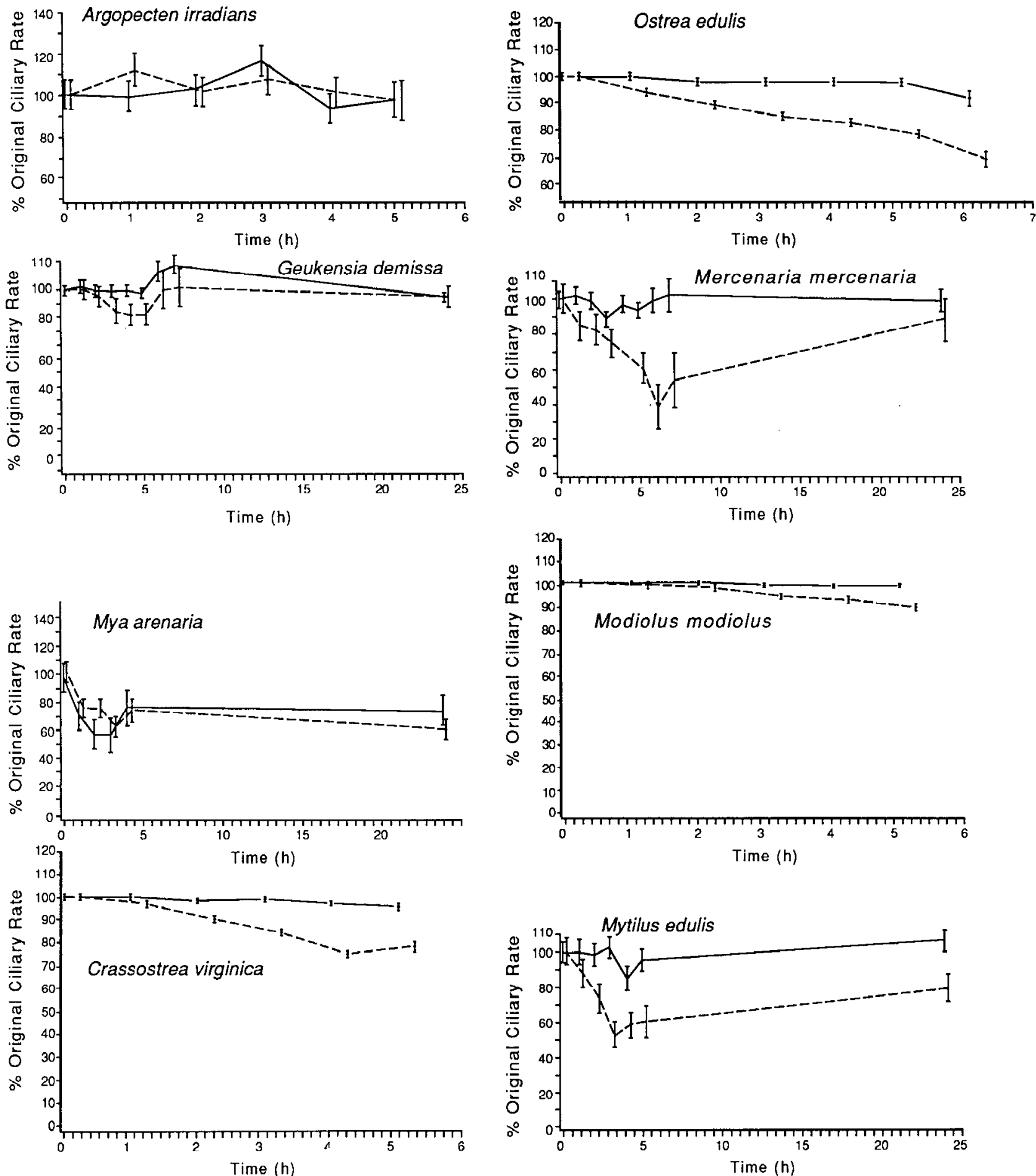

Figure 1. The effect of Aureococcus anophagefferens (brown tide) on the lateral cilia of eight species of bivalve mollusks. Solid line: control (c); dashed line: brown tide (BT). Number of gills: Argopecten: $\mathrm{c}=9$, BT $=13 ;$ Geukensia: $\mathrm{c}=9, \mathrm{BT}=17 ;$ Mya: $\mathrm{c}=6$, BT $=12$; Crassostrea and Ostrea $: \mathrm{c}=8, \mathrm{BT}=24$; Mercenaria: $\mathrm{c}=8, \mathrm{BT}=15 ;$ Modiolus: $\mathrm{c}=6, \mathrm{Bl}=18 ;$ Mytilus: $\mathrm{c}=9, \mathrm{BT}=16$. Error bars are \pm 1 standard error. Although readings were taken at the same times for both controls and treatments, they have been offset for the sake of clarity in this and subsequent figures. 


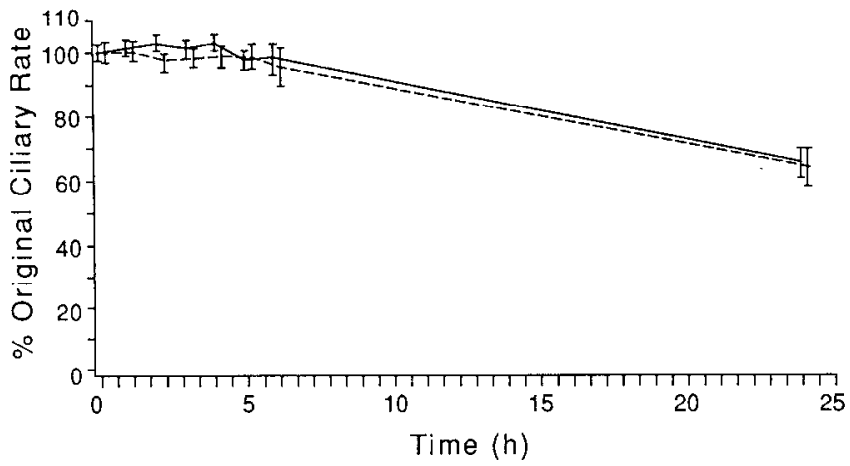

Figure 2. The effect of water, from which Aureococcus anophagefferens had been removed hy filtration, on the lateral cilia of Mytilus edulis. Solid line: control $(\mathrm{n}=6)$; dashed line: treatment $(\mathrm{n}=12)$. Error bars are \pm 1 standard error.

contrast to gills exposed to $A$. anophagefferens without a pretreatment of ergometrine $\left(\mathrm{F}_{14}^{1}=16.49, P=.001\right.$, Fig. 4).

We tested the hypothesis that the isolated gills were digesting the extracellular polysaccharide coat of $A$. anophagefferens, which was described by Sieburth et al. (1988), by exposing cultures of $A$. anophagefferens to amylase. Exposure of isolated gills to seawater containing amylase had no effect upon lateral ciliary activity ( $F_{15}$ $=.12, P=.74$ ). Exposure of isolated gills of $M$. edulis to filtered seawater which had contained $A$. anophagefferens treated with amylase resulted in decreased lateral ciliary activity $\left(\mathrm{F}_{16}^{\mathrm{i}}=7.19, P=.02\right.$, Fig. 5). There was no difference in the activity of lateral cilia of isolated gills exposed to the enzymatically treated $A$. anophagefferens filtrate or to untreated $A$. anophagefferens $\left(\mathrm{F}_{14}^{1}=.02, P\right.$ $=.88$ ).

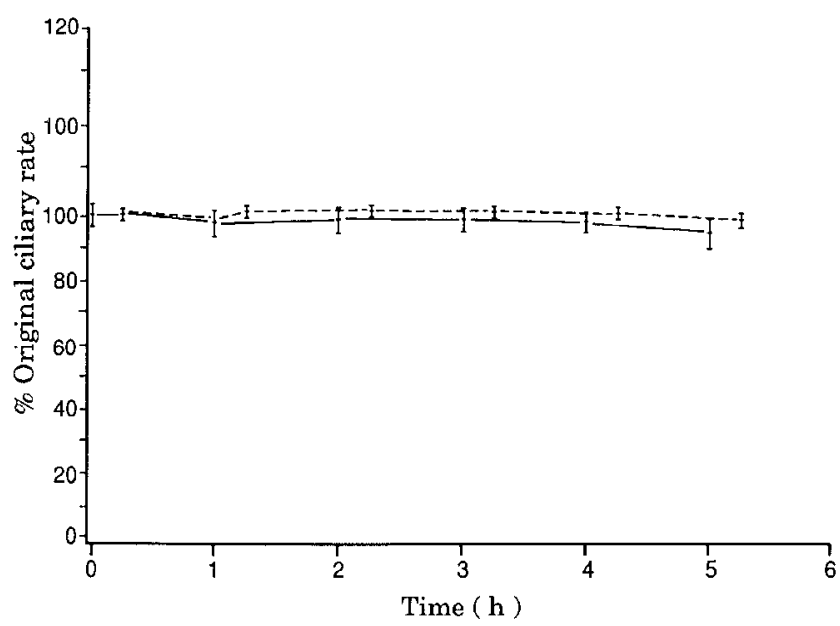

Figure 3. The effect of polystyrene microspheres on the lateral cilia of Mytilus edulis. Solid line: control $(\mathrm{n}=8)$; dashed line: treatment ( $\mathrm{n}$ $=11$ ). Error bars are \pm 1 standard error.
Table II

Summary of responses of lateral cilia to Aureococcus anophagefferens and exogenously applied $10^{-1} \mathrm{M}$ dopamine

\begin{tabular}{|c|c|c|}
\hline Species & $\begin{array}{l}\text { Response to } \\
\text { Aureococcus }\end{array}$ & $\begin{array}{c}\text { Response to } \\
\text { dopamine }\end{array}$ \\
\hline Argopectin irradians & - & - \\
\hline Geukensia demissa & - & - \\
\hline Mya arenaria & - & - \\
\hline Crassostrea virginica & inh & inh \\
\hline Ostrea edulis & inh & inh \\
\hline Mercenaria mercenaria & inh & inh \\
\hline Modiolus modiolus & inh & inh \\
\hline Mytilus edulis & inh & inh \\
\hline
\end{tabular}

$-=$ no response, inh $=$ inhibition.

To test if the inhibition was caused by the same type of compound in the experiment with the enzymatically treated $A$. anophagefferens filtrate and the experiments with intact $A$. anophagefferens, we exposed isolated gills to ergometrine, as described previously, then exposed the gills to the water from $A$. anophagefferens treated with amylase. The ergometrine blocked the inhibition of the lateral cilia brought about by the $A$. anophagefferens amylase filtrate $\left(\mathrm{F}_{12}^{1}=5.39, P=.04\right.$, Fig. 6). In addition, there was no difference in the rates of untreated gills, gills exposed to ergometrine and the $A$. anophagefferens amylase filtrate, and gills exposed to ergometrine and intact $A$. anophagefferens $\left(\mathrm{F}_{5}^{2}=1.51, P=.31\right)$.

\section{Discussion}

The bivalves whose lateral cilia were inhibited by $A$. anophagefferens were the same species whose lateral cilia were inhibited by dopamine. There are three possibilities

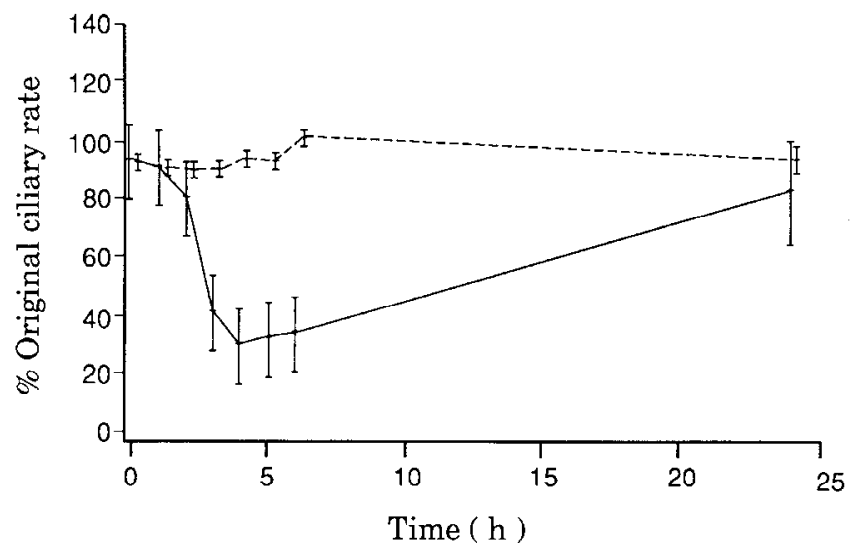

Figure 4. The effect of exposing the gills of $M$. edulis to $10^{-5} M$ ergometrine and then to Aurecoccus anophagefferens. Solid line: control (exposed to $A$. anophagefferens, $\mathrm{n}=8$ ); dashed line: treatment $(\mathrm{n}=10)$. Error bars are \pm 1 standard error. 


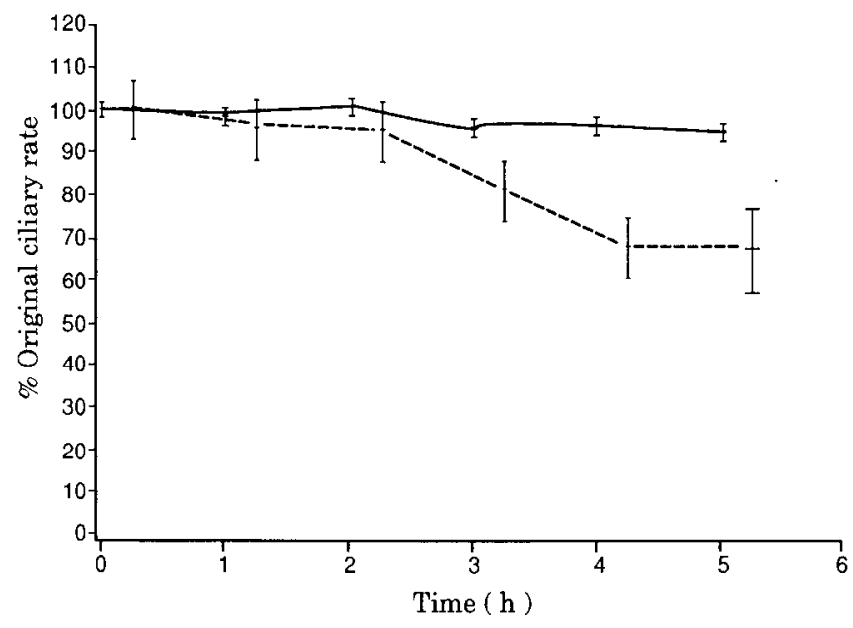

Figure 5. The effect of exposing Aurecoccus anophagefferens to amylase, filtering the water, and exposing the gills of Mytilus edulis to the filtrate. Solid line: control $(n=9)$; dashed line: treatment $(n=10)$. Error bars are \pm 1 standard error.

that could explain this correlation. First, $A$. anophagefferens could release dopamine upon contact with the bivalve gill. We think that this is unlikely because the oxidation products of dopamine are readily visible in seawater (pers. obs.) and we have not observed this characteristic discoloration in any of our experiments with either intact A. anophagefferens, or with the water from enzymatically treated $A$. anophagefferens. Moreover, the inhibitory effects of exogenously applied dopamine typically appear within 2 to $3 \mathrm{~min}$ and disappcar within 20 to $30 \mathrm{~min}$ after application (Catapane et al., 1978; pers. obs.), while the effects of the water from enzymatically treated $A$. anophagefferens did not appear for several hours and persisted for at least $5 \mathrm{~h}$. Second, the inhibition could be caused by a dopamine-mimetic compound. Third, the inhibition could be the result of the stimulation of branchial nerve fibers in the gill. These fibers innervate the lateral ciliated cells and contain dopamine (Paparo, 1972; Stefano and Aiello, 1975). Our experiments cannot distinguish between these latter two possibilities because the dopamine antagonist ergometrine would block the inhibition of the lateral cilia brought about by exposure to $A$. anophagefferens in either case. We think that it is unlikely that the effects of $A$. anophagefferens are brought about by a direct influx of calcium into the lateral ciliated cells. If this were the case, inhibition of the lateral cilia would probably have occurred in all of the species tested, and the effects would not have been blocked by ergometrine.

Tracey (1988) found decreased clearance rates in both Mytilus and Mercenaria exposed to A. anophagefferens, and our results on isolated gills are parallel to his. Bricelj and Kuenstner (1989) found that A. anophagefferens inhibited clearance rates in juvenile Argopecten irradians; however, we found no inhibition of isolated gills of adult
A. irradians. Several possibilities exist for this discrepancy. Sensitivity to $A$. anophagefferens could be age dependent, or the $A$. anophagefferens dopamine-mimetic could interact directly with the visceral ganglia in intact scallops to bring about lateral ciliary inhibition via nerves innervating the gills rather than acting directly on the gills, because the lateral cilia of isolated scallop gills are unaffected by dopamine.

Physical contact between a bivalve and $A$. anophagefferens is apparently necessary for inhibition. Tracey (1988) found no inhibition of clearance rates when $M$. edulis were exposed to Narragansett Bay water from which $A$. anophagefferens had been removed by filtration. Ward and Targett (1989) found similar results with $M$. edulis exposed to filtrates of cultured $A$. anophagefferens. We have found similar results with isolated gills. Taken together, these results indicate that $A$. anophagefferens is not excreting an inhibitory compound into the water. In addition, Ward and Targett (1989) found that exposing $M$. edulis to lysed cell filtrates of $A$. anophagefferens had no effect on clearance rates, indicating that the inhibitory compound is not intracellular in origin.

The inhibition of ciliary activity of isolated gills, and decreased clearance in whole animals, is not caused by the high density of small particulates present during a brown tide. Tracey (1988) found no inhibition of clearance in $M$. edulis exposed to high densities of kaolin clay particles, and we have found similar results with isolated gills exposed to polystyrene microspheres.

Pequignat (1973) found that the gills of $M$. edulis secrete amylase, and Sieburth et al. (1988) described A. anophagefferens as having ". . . a diffuse, sometimes copious layer of exocellular organic material which is probably

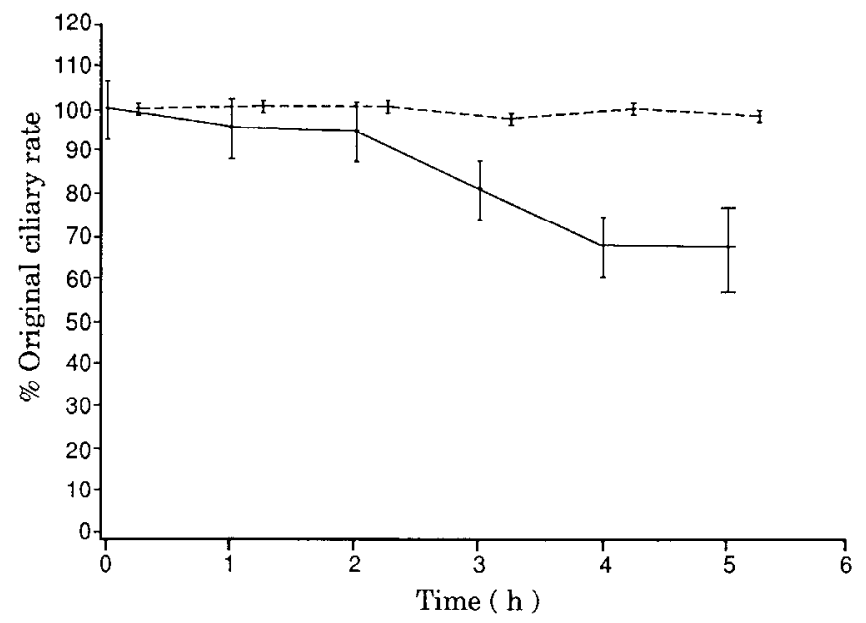

Figure 6. The effect of pretreating the gills of Mytilus edulis with $10^{-5} M$ ergometrine and then exposing the gills to the filtrate of $A$. anophagefferens treated with amylase. Solid line: filtrate of $A$. anophagefferens treated with amylase $(n=10)$; dashed line: treatment $(n=4)$. See text for further control comparisons. 
polysaccharide. . . O" Our results demonstrate that the inhibitory compound is released upon exposure of $A$. anophagefferens to amylase. That this inhibitory compound is similar to that released upon exposure of intact $A$. anophagefferens to bivalve gills is indicated by the blockage of inhibition by pre-treatment of the gills with ergometrine in both instances.

The time for inhibition of clearance rates in bivalves exposed to $A$. anophagefferens is much faster than the time for inhibition of the lateral cilia of isolated gills. Tracey (1988) found inhibition of clearance rates after only $20 \mathrm{~min}$ of exposure to $A$. anophagefferens, whereas we found that the time for inhibition was much slower in isolated gills. These differences should, in fact, be expected for the following reason. The ingestion of $A$. anophagefferens by whole animals would result in the faster digestion of the extracellular coat in comparison to the digestion by isolated gills because digestion would occur not only on the gills but also in the digestive system of a whole animal.

In summary, we propose that the inhibition of clearance in bivalve mollusks exposed to A. anophagefferens is brought about by the digestion of the extracellular coat, releasing a dopamine-mimetic compound, which brings about the arrest of the lateral cilia in certain species.

\section{Acknowledgments}

We thank Jan Barter for assistance in culturing $A$. anophagefferens; Christy Draper, Karen Emery, and Christy Leigh for assistance in measuring ciliary rates; and Mike Castagna and Steve Tettlebach for providing bivalves.

This paper is funded, in part, by grant/cooperative agreement (NA-90-AA-H SK030) from the National Oceanic and Atmospheric Administration awarded to the New England Fisheries Development Association. The views expressed herein are those of the authors and do not necessarily reflect the views of NOAA or any of its subagencies.

\section{Literature Cited}

Ahlijanian, M. K., and D. M. Cooper. 1988. Distinct interactions between $\mathrm{Ca}^{2+} /$ calmondulin and neurotransmitter stimulation of adenylate cyclase in striatum and hippocampus. Cell. Mol. Neurobiol. 8: 459469 .

Aiello, E. L. 1960. Factors affecting ciliary activity on the gill of the mussel Mytilus edulis. Physiol. Zool. 23: 120-135.

Bayne, B. L., and R. C. Newell. 1983. Physiological energetics of marine molluscs. Pp. 407-515 in The Mollusca, V. 4, Physiology, Part I, A.S.M. Saleuddin and K. M. Wilbur, eds. Academic Press, New York.

Bricelj, V. M., J. Epp, and R. E. Malouf. 1987. Intraspecific variation in reproductive and somatic growth cycles of bay scallops Argopecten irradians. Mar. Ecol. Prog. Ser. 36: 123-137.

Bricelj, V. M., N. S. Fisher, J. B. Guckert, and F. E. Chu. 1989. Lipid composition and nutritional value of the brown tide alga Aureococcus anophagefferens. Pp. 85-100 in Novel Phytoplankton Blooms, E. M.
Cosper, V. M. Bricelj, and E. J. Carpenter, eds. Springer-Verlag, New York.

Bricelj, V. M., and S. H. Kuenstner. 1989. Fffects of the "brown tide" on the feeding physiology and growth of bay scallops and mussels. Pp. 491-509 in Novel Phytoplankton Blooms, E. M. Cosper, V. M. Bricelj, and E. J. Carpenter, eds. Springer-Verlag, New York.

Catapane, E. J., G. B. Stefano, and E. Aiello. 1978. Pharmacological study of the reciprocal dual innervation of the lateral ciliated gill epithelium by the CNS of Mytilus edulis (Bivalvia). J. Exp. Biol. 74: 101-113.

Catapane, E. J., G. B. Stefano, and E. Aiello. 1979. Neurophysiological correlates of the dopaminergic cilio-inhibitory mechanism of Mytilus edulis. J. Exp. Biol. 83: 315-323.

Catapane, E. J. 1983. Comparative study of the control of lateral ciliary activity in marine bivalves. Comp. Biochem. Physiol. 75C: 403-405.

Cosper, E. M., W. C. Dennison, E. J. Carpenter, V. M. Bricelj, J. G. Mitchell, S. H. Kuenstner, D. Coleflesh, and M. Dewey. 1987. Recurrent and persistent brown tide blooms perturb coastal marine ecosystem. Estuaries 10: 284-290.

Draper, C., L. Gainey, S. Shumway, and L. Shapiro. 1990. Effects of Aureococcus anophagefferens ("Brown Tide") on the lateral cilia of 5 species of bivalve molluscs. Pp. 128-131 in Toxic Marine Phytoplankton, E. Graneli, B. Sundstrom, L. Elder, and D. M. Anderson, eds. Elsevier, New York.

Felder, C. C., M. Belcher, and P. A. Jose. 1989. Dopamine-1-mediated stimulation of phospholipase $\mathrm{C}$ activity in rat renal cortical membranes. J. Biol. Chem. 264: 8739-8745.

Gainey, L. F., Jr., and S. E. Shumway. 1989. Effects of Aureococcus anophagefferens ("brown tide") on the lateral ciliary activity of bivalve molluscs. Am. Zool. 29: 72A.

Gallager, S. M., D. K. Stoecker, and V. M. Bricelj. 1989. Effects of the brown tide alga on growth, feeding physiology and locomotory behavior of scallop larvae (Argopecten irradians). Pp. 511-541 in Novel Phytoplankton Blooms, E. M. Cosper, V. M. Bricelj and M. J. Carpenter, eds. Springer-Verlag, New York.

Guillard, R. L. 1975. Culture of phytoplankton for feeding marine invertebrates. Pp. 29-60 in Culture of Marine Invertebrates, W. L, Smith and M. H. Chanley, eds. Plenum Press, New York.

Mahan, L. C., R. M. Burch, F. J. Monsma, Jr., and D. R. Sibley. 1990. Expression of striatal D1 dopamine receptors coupled to inositol phosphate production and $\mathrm{Ca}^{2+}$ mobilization in Xenopus oocytes. Proc. Natl. Acad. Sci. U.S.A. 87: 2196-2200.

Mohlenberg, F., and H. U. Riisgard. 1978. Efficiency of particle retention in 13 species of suspension feeding bivalves. Ophelia 17: 239246.

Murakami, A. 1983. Control of ciliary beat frequency in Mytilus. $J$. Submicrosc. Cylol. 15: 313-316.

Olsen, P. 1986. Occurrence and distribution of brown tide in New Jersey. P. 10 in Proc. Emergency Conference on "Brown Tide," Oct. 23-24, 1986, Hauppauge, Long Island. State Dept. New York State, Albany, New York.

Paparo, A., and E. Aiello. 1970. Cilio-inhibitory effects of branchial nerve stimulation in the mussel, Mytilus edulis. Comp. gen. Pharmacol. 1: 241-250.

Paparo, A., and C. E. Finch. 1972. Catecholamine localization, content, and metabolism in the gill of two lamellibranch molluscs. Comp. Gen. Pharmacol. 3: 303-309

Paparo, A. A., and J. A. Murphy. 1975. The effect of $\mathrm{Ca}$ on the rate of beating of lateral cilia in Mytilus edulis-II. a response to electrical stimulation of the branchial nerve. Comp. Biochem. Physiol. 50C: 15-19.

Paparo, A. 1972. Innervation of the lateral cilia in the mussel Mytilus edulis L. Biol. Bull. 143: 592-604. 
Paparo, A. 1980. The regulation of intracellular calcium and the release of neurotransmitters in the mussel, Mytilus edulis. Comp. Biochem. Physiol. 66A: 517-520.

Paparo, A. 1985. The relationship between lamellar-type cytosomes, DOPA decarboxylase, and lateral ciliary activity of the oyster Crassostrea virginica (Gmelin): response to salinity change. J. Exp. Mar. Biol. Ecol. 87: 133-143.

Pequignat, E. 1973. A kinetic and autoradiographic study of the direct assimilation of amino acids and glucose by organs of the mussel Mytilus edulis. Mar. Biol. 19: 227-244.

Shumway, S. E. 1990. A review of the effects of algal blooms on shellfish and aquaculture. $J$. World Aquaculture Soc. 21: 65-104.

Sieburth, J. McN., P. W. Johnson, and P. E. H. Hargraves. 1986. Pardococcus anorexus nom. prov., a bloom-forming chrysophycean picoplankter inducing anorexia in filter-feeding animals in Narragansett Bay, R. I. during summer 1985: ultrastructure and predators. ASLO Abstracts June 1986, p. 119.

Sieburth, J. McN., P. W. Johnson, and P. E. Hargraves. 1988. Ultrastructure and ecology of Aureococcus anophagefferens gen. et sp. nov. (Chrysophyceae): the dominant picoplankter during a bloom in Narragansett Bay, Rhode Island, Summer 1985. J. Phycol. 24: $416-425$.

Stefano, G. B., and E. Aiello. 1975. Histofluorescent localization of serotonin and dopamine in the nervous system and gill of Mytilus edulis (Bivalvia). Biol. Bull. 148: 141-156.

Stommel, E. W., and R. E. Stephens. 1985. Cyclic AMP and calcium in the differential control of Mytilus edulis cilia. J. Comp. Physiol. A 157: 451-459.

Tracey, G. A. 1985. Picoplanktonic algal bloom causes catastrophic mussel kill in Narragansett Bay, Rhode Island. Trans. Am. Geophys. Union 66: 1303.

Tracey, G. A. 1988. Feeding reduction, reproductive failure, and mortality in Mytilus edulis during the 1985 "brown tide" in Narragansett Bay, Rhode Island. Mar. Ecol. Prog. Ser. 50: 73-81.

Tracey, G. A., P. W. Johnson, R. W. Steele, P. E. Hargraves and J. McN. Sieburth. 1988. A shift in photosynthetic picoplankton composition and its effect on bivalve mollusc nutrition: the 1985 "brown tide" in Narragansett Bay, Rhode Island. J. Shellfish Res. 7: 671-675.

Tracey, G., R. Steele, and L. Wright. 1990. Variable toxicity of the brown tide organism, Aureococcus anophagefferens, in relation to environmental conditions for growth. Pp. 233-237 in Toxic Marine Phytoplankton, E. Graneli, B. Sundstrom, L. Edler, and D. M. Anderson, eds. Elsevier, New York.

Walter, M. F., and P. Satir. 1978. Calcium control of ciliary arrest in mussel gill cells. J. Cell Biol. 79; 110-120.

Ward, J. E., and N. M. Targett. 1989. Are metabolites from the brown tide alga, Aureococcus anophagefferens, deleterious to mussel feeding behavior? Pp. 543-556 in Novel Phytoplankton Blooms, E. M. Cosper, V. M. Bricelj and M. J. Carpenter, eds. Springer-Verlag, New York.

Welsh, J. H., R. I. Smith, and A. E. Kammer. 1968. Laboratory Exercises in Invertebrate Physiology, 3rd. ed. Burgess, Minneapolis. 